DOI: $10.14451 / 1.193 .179$

\title{
ПРОГНОЗИРОВАНИЕ ОБЪЕМА ДОТАЦИЙ ПРЕДОСТАВЛЯЕМЫХ НА СБАЛАНСИРОВАННОСТЬ РЕГИОНАЛЬНЫХ БЮДЖЕТОВ
}

\author{
(c) 2020 Белостоцкий Алексей Александрович \\ кандидат экономических наук, доцент \\ Курский филиал Финансового университета при Правительстве РФ, Россия, Курск \\ E-mail: a.a.belostotskiy@yandex.ru
}

Рассмотрены особенности прогнозирования объема дотаций предоставляемых на сбалансированность региональных бюджетов, что позволит рассчитать необходимые объемы финансовой помощи и выявить тенденции снижения размеров финансовой помощи региональным бюджетам.

Ключевые слова: межбюджетные трансферты, дотации, региональные бюджеты, сбалансированность бюджета, государственный долг, дефицит бюджета

В настоящее время в системе государственных и муниципальных финансов сложилась такая ситуация, когда уровень распределяемых межбюджетных трансфертов из федерального бюджета достаточный, при этом, наблюдается крайне низкая эффективность их применения. В этой связи перераспределение межбюджетных трансфертов должно отличаться высокой степенью эффективности для системы государственных и муниципальных финансов, в частности, профессор А.М. Лавров считает, что «распределение трансфертов должно, как минимум, не препятствовать достижению:

а) экономической эффективности - формированию и поддержанию долгосрочных институциональных стимулов для региональных властей проводить структурные преобразования, поддерживать конкурентную среду, благоприятный инвестиционный и предпринимательский климат;

б) бюджетной ответственности - управлению общественными финансами от имени и в интересах населения, при максимально эффективном использовании налоговых и иных ресурсов соответствующих территорий, прозрачности и подотчетности налогово-бюджетной политики;

в) политической консолидации - достижению общественного согласия по вопросам распределения между уровнями бюджетной системы и регионами финансовых ресурсов, созданию условий для эффективного выполнения региональными властями своих полномочий в рамках гражданского общества, упрочению территориальной целостности страны [1. С. 87].

Бюджетным кодексом Российской Федера- ции к основным условиям предоставления межбюджетных трансфертов отнесен контроль за исполнением органами местного самоуправления бюджетных полномочий в зависимости от того, к какой группе муниципальных образований по доле дотаций (с учетом замещения дополнительными дифференцированными нормативами отчислений от НДФЛ) в собственных бюджетных доходах относится муниципальное образование (таблица 1).

Ключевым видом межбюджетных трансфертов из федерального бюджета бюджетам субъектов Российской Федерации являются дотации на выравнивание бюджетной обеспеченности субъектов Российской Федерации, которые предоставляются субъектам Российской Федерации, чей уровень расчетной бюджетной обеспеченности не превышает уровня, установленного в качестве критерия выравнивания

При этом из федерального бюджета будет оказываться дополнительная финансовая помощь регионам в виде дотаций на поддержку мер по обеспечению сбалансированности региональных бюджетов и грантов. В 2020 году их объем составит 204,3 млрд. рублей, в 2021году 198,5 млрд. рублей и в 2022году - 198,5 млрд. рублей, в том числе гранты в объеме 50,0 млрд. рублей ежегодно (рисунок 1).

Совокупный государственный долг субъектов Российской Федерации и долг муниципальных образований, входящих в состав субъекта Российской Федерации, по состоянию на 1 января 2020 года составил 2493,4 млрд. рублей и по сравнению с 1 января 2019 года (2 578,2 млрд. рублей) снизился на 84,8 млрд. рублей, или на $3,3 \%$. Государственный долг субъектов Россий- 
Таблица 1. Распределение межбюджетных трансфертов из федерального бюджета бюджетам субъектов Российской Федерации, млрд. рублей

\begin{tabular}{|c|c|c|c|c|c|}
\hline \multicolumn{2}{|c|}{ Показатель } & 2019 год & 2020 год & 2021 год & 2022 год \\
\hline \multirow{2}{*}{ Дотации } & млрд. рублей & 925,5 & 932,1 & 939,4 & 952,3 \\
\hline & в \% к МБТ (всего) & 39,8 & 36,4 & 36,7 & 38,4 \\
\hline \multirow{2}{*}{ Субсидии } & млрд. рублей & 625,4 & 765,8 & 715,3 & 713,2 \\
\hline & в \% к МБТ (всего) & 26,2 & 29,9 & 28,0 & 28,8 \\
\hline \multirow{2}{*}{ Субвенции } & млрд. рублей & 366,9 & 514,7 & 517,1 & 532,1 \\
\hline & в \% к МБТ (всего) & 15,4 & 20,1 & 20,2 & 21,5 \\
\hline \multirow{2}{*}{$\begin{array}{l}\text { Иные межбюд- } \\
\text { жетные транс- } \\
\text { ферты }\end{array}$} & млрд. рублей & 445,7 & 351,4 & 385,4 & 280,2 \\
\hline & в \% к МБТ (всего) & 18,6 & 13,7 & 15,1 & 11,3 \\
\hline \multirow{2}{*}{ Всего } & млрд. рублей & 2390,4 & 2564,0 & 2557,2 & 2477,8 \\
\hline & \% к ВВП & 2,2 & 2,3 & 2,1 & 1,9 \\
\hline
\end{tabular}

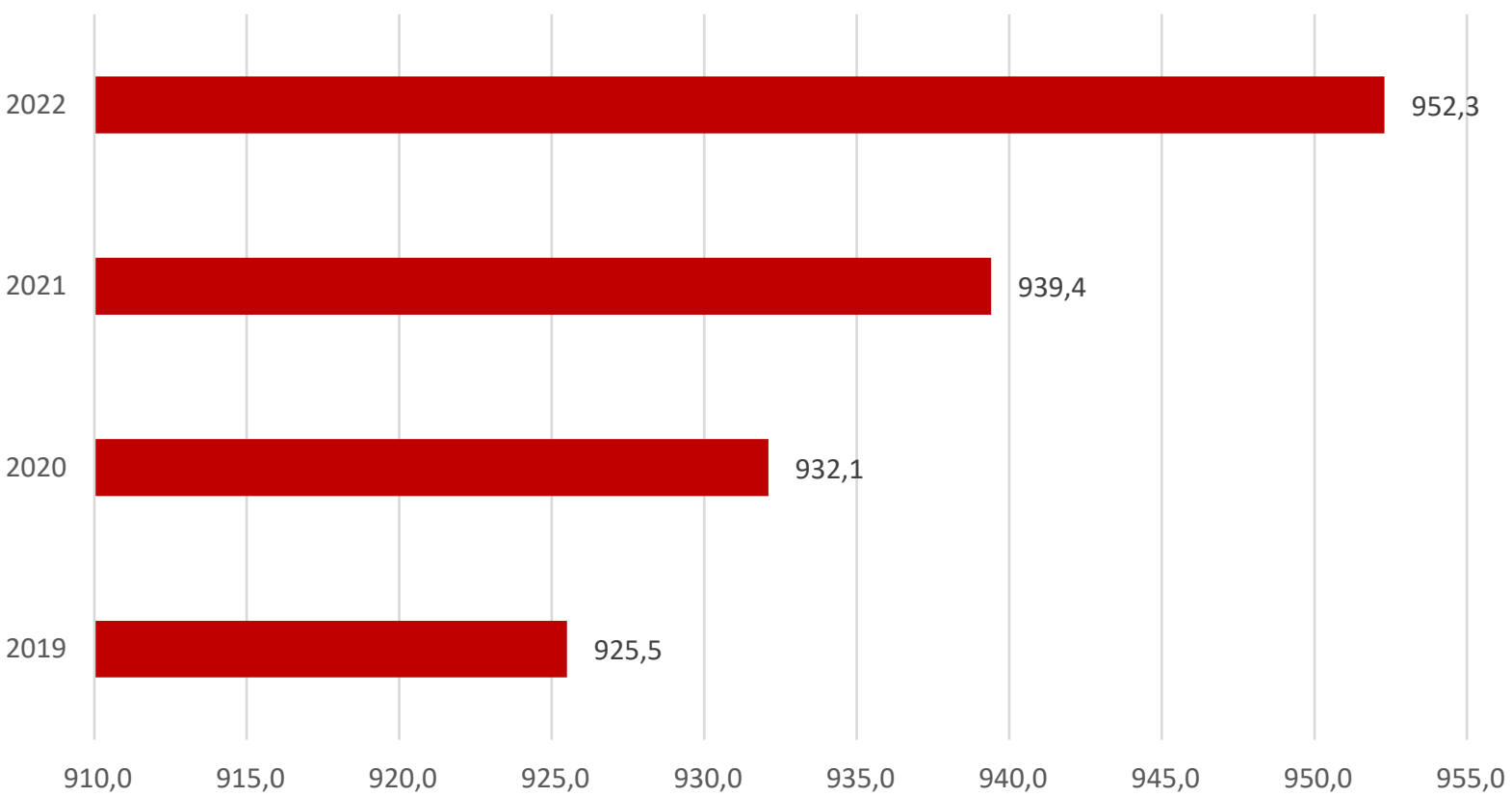

Рисунок 1. Объем дотаций, перераспределяемых из федерального бюджета РФ, млрд. рублей

ской Федерации по состоянию на 1 января 2020 года составил 2113,0 млрд. рублей и уменьшился по сравнению с 1 января 2019 года на 93,3 млрд. рублей, или на $4,2 \%$ [3].

При этом на 1 декабря 2019 года госдолг субъектов Российской Федерации составлял 1916,3 млрд. рублей. Таким образом, за декабрь госдолг регионов увеличился на 196,7 млрд. рублей, или на 10,3\% (за счет увеличения задолженности по кредитам от кредитных организаций на 178,4 млрд. рублей, или на 44,9\%).

Рост государственного долга субъектов Российской Федерации за январь - декабрь 2019 года наблюдался в 12 субъектах Российской Фе- дерации, из них наибольший в Иркутской области - на 38,2\%, Московской области - на 30,4\%, Республике Калмыкия - на 16,7\%, Томской области - на $11,3 \%$, Тамбовской области - на $10,8 \%$, Свердловской области - на 6\%, Хабаровском крае - на 5,8\%. Снизился государственный долг в 68 регионах, в трех регионах остался на уровне начала года (г. Москва, г. СанктПетербург, Курганская область). Госдолг не имеют два субъекта Российской Федерации (г. Севастополь и Сахалинская область).

Сохраняется тенденция снижения задолженности регионов по кредитам от кредитных организаций и бюджетным кредитам. На 1 января 
2020 года задолженность по кредитам от кредитных организаций снизилась по сравнению с началом года на 60,3 млрд. рублей (на 9,5\%) и составила 575,8 млрд. рублей, по государственным гарантиям субъектов Российской Федерации на 16,1 млрд. рублей (на 22,6\%) и составила 55,4 млрд. рублей, по бюджетным кредитам, привлеченным в бюджет субъекта Российской Федерации от других бюджетов бюджетной системы Российской Федерации,- на 53,8 млрд. рублей, или на 5,7\%, и составила 886,2 млрд. рублей. Задолженность по государственным ценным бумагам субъектов Российской Федерации, напротив, выросла - на 37,2 млрд. рублей (на 6,7\%) и составила 588,5 млрд. рублей.

В 2019 году объем государственного долга субъектов Российской Федерации составил $22,5 \%$ объема налоговых и неналоговых доходов бюджетов регионов (в 2018 году - 25,3\%, в 2017 году - 30,5\%, в 2016 году - 33,8\%). Выше 90\% указанное отношение сложилось в четырех субъектах Российской Федерации: в Республике Мордовия - 211,2\%, в Республике Хакасия 98,4\%, в Псковской области - 91,9\%, в Костромской области - 90,1\% [2].

Объем долга муниципальных образований, входящих в состав субъектов Российской Федерации, на 1 января 2020 года составил 380,5 млрд. рублей (вырос по сравнению с началом года на 8,6 млрд. рублей, или на 2,3\%). При этом на 1 декабря 2019 года он составлял 348,1 млрд. рублей (увеличился за декабрь на 32,4 млрд. рублей, или на 9,3\%). В структуре долга муниципальных образований наибольший удельный вес занимают кредиты от кредитных организаций (68,2\%) и бюджетные кредиты от других бюджетов бюджетной системы Российской Федерации (24,2\%). Учитывая объём долга совокупный объем средств ФНБ в рублевом эквиваленте на 1 января 2020 года составил 7773 062,6 млн. рублей, что на 3737 015,0 млн. рублей, или в 1,9 раза, больше, чем на начало года (4036 047,6 млн. рублей).

В июле 2019 года в соответствии с приказом Минфина России от 17 июля 2019 г. № 364 «Об использовании дополнительных нефтегазовых доходов федерального бюджета, поступивших в 2018 году, на формирование Фонда национального благосостояния» средства в ино- странной валюте в сумме 30206,6 млн. долларов США, 25 742,9 млн. евро и 5064,7 млн. фунтов стерлингов, приобретенные за счет средств федерального бюджета в пределах объема дополнительных нефтегазовых доходов федерального бюджета за 2018 год, зачислены на счета в Банке России по учету средств ФНБ в соответствующих иностранных валютах [5].

Для снижения дотационной нагрузки регионов представляется возможным разработка направлений совершенствования системы прогнозирования финансовой помощи территориальным бюджетам.

Бюджетный кодекс Российской Федерации предусматривает следующие ограничения по показателям дефицита местного бюджета и муниципального долга (таблица 2).

Исходя из этого, субъект РФ должен обеспечить в срок до 15 ноября текущего финансового года утверждение финансовым органом субъекта Российской Федерации перечня муниципальных образований, в отношении которых начиная с очередного финансового года применяются указанные выше ограничения (а также тех, в отношении которых ограничения не применяются, то есть с уровнем дотационности менее 5\% или не получающих дотации). В течение текущего финансового года и по итогам исполнения бюджета за отчетный финансовый год финансовый орган субъекта Российской Федерации осуществляет мониторинг выполнения муниципальными образованиями установленных для них ограничений и принимает соответствующие решения в отношении муниципальных образований, не соблюдающих указанные ограничения [4].

Указанные мероприятия, а также соблюдение регионами условий реструктуризации бюджетных кредитов будет способствовать более точному прогнозированию объема дотаций, предоставляемых на сбалансированность региональных бюджетов, а также сокращению государственного долга субъектов Российской Федерации, в том числе рыночной задолженности и сокращению расходов на обслуживание государственного долга регионов и высвобождению средств для финансирования приоритетных расходных обязательств. 
Таблица 2. Ограничения по показателям дефицита и долга

\begin{tabular}{|c|c|c|}
\hline Показатель & $\begin{array}{l}\text { Ограничение } \\
\text { для всех МО }\end{array}$ & $\begin{array}{l}\text { Ограничение } \\
\text { для МО груп- } \\
\text { пы } 3\end{array}$ \\
\hline $\begin{array}{l}\text { Дефицит местного бюджета, в процентах от утвержденного общего } \\
\text { объема доходов местного бюджета без учета утвержденного объема } \\
\text { безвозмездных поступлений и(или) поступлений налоговых доходов } \\
\text { по дополнительным дифференцированным нормативам отчислений от } \\
\text { НДФл }\end{array}$ & $\leqslant 10 \%$ & $\leqslant 5 \%$ \\
\hline $\begin{array}{l}\text { Объем муниципального долга, в процентах от утвержденного общего } \\
\text { объема доходов местного бюджета без учета утвержденного объема } \\
\text { безвозмездных поступлений и(или) поступлений налоговых доходов } \\
\text { по дополнительным дифференцированным нормативам отчислений от } \\
\text { НДФл }\end{array}$ & $\leqslant 100 \%$ & $\leqslant 50 \%$ \\
\hline $\begin{array}{l}\text { Объем расходов на обслуживание муниципального долга, в процентах } \\
\text { от общего объема расходов местного бюджета, за исключением объема } \\
\text { расходов, которые осуществляются за счет субвенций, предоставляемых } \\
\text { из бюджетов }\end{array}$ & $\leqslant 10 \%$ & - \\
\hline $\begin{array}{l}\text { Годовая сумма платежей по погашению и обслуживанию муниципаль- } \\
\text { ного долга, возникшего по состоянию на } 1 \text { января очередного финан- } \\
\text { сового года, в процентах от утвержденного общего объема налоговых, } \\
\text { неналоговых доходов местного бюджета и дотаций из бюджетов }\end{array}$ & $\leqslant 20 \%$ & - \\
\hline
\end{tabular}

\section{Библиографический список}

1. Лавров, А.М. Логика и перспективы бюджетных реформ в России: в поисках «оптимальной децентрализации». Цикл публикаций и документов (1998-2019 гг.) / М.: Изд. дом Высшей школы экономики.-2019.832 c.

2. Правительство Российской Федерации: официальный сайт. URL: http:/government.ru/ (дата обращения: 27.11.2020).

3. Министерство финансов РФ. Фонд национального благосостояния: официальный сайт. URL: http://minfin. $\mathrm{ru} /$ (дата обращения: 18.11.2020).

4. Счетная палата Российской Федерации: официальный сайт. URL: http://www.ach.gov.ru/ (дата обращения: 12.11.2020)

5. Федеральное казначейство: официальный сайт Казначейства России. URL: http://roskazna.ru/ (дата обращения: 20.11.2020) 